\author{
MAŁGORZATA DUDZIAK-KOWALSKA \\ BARBARA JANCZAK
}

\title{
Z dziejów średniego szkolnictwa bibliotekarskiego. Liceum bibliotekarskie w Krakowie (1947-1960)
}

\begin{abstract}
STReSzCzenie. W okresie powojennym istotną rolę w przygotowaniu kadry bibliotekarskiej odegrały placówki oświatowe kształcące na poziomie średnim (licealnym). Niniejszy artykuł jest próbą przybliżenia tego okresu na przykładzie krakowskiego liceum bibliotekarskiego. Opracowanie oparte jest głównie na materiałach archiwalnych. Omówiono takie aspekty funkcjonowania szkoły, jak jej tworzenie, organizacja i zarządzanie, nadzór zewnętrzny oraz powody jej rozwiązania. Poruszono też zagadnienia programów nauczania, kadry pedagogicznej i jakości kształcenia oraz charakterystyki uczniów i absolwentów szkoły. Nakreślono sylwetki dyrektorów i bardziej znaczących pedagogów. Jakkolwiek całościowa ocena działalności szkoły nie rysuje się jednoznacznie, trudno nie docenić jej zasług w okresie braku wykwalifikowanych bibliotekarzy. Należy przypuszczać, że ten skromny przyczynek do dziejów szkolnictwa bibliotekarskiego pobudzi badaczy do dalszych poszukiwań i pogłębionych analiz.
\end{abstract}

SŁowA KLUCzowe: kształcenie bibliotekarzy, średnie szkolnictwo bibliotekarskie, liceum bibliotekarsko-księgarskie w Krakowie, 2-letnie Liceum Bibliotekarskie w Krakowie, 4-letnie Liceum Bibliotekarskie w Krakowie.

\section{Wstęp}

Dekret o bibliotekach i opiece nad zbiorami bibliotecznymi z 17 kwietnia 1946 roku$^{1}$ nałożył na biblioteki między innymi obowiązek posiadania personelu należycie przygotowanego do pracy z książką i czytelnikiem.

${ }^{1}$ Dekret z dnia 17 kwietnia 1946 roku o bibliotekach i opiece nad zbiorami bibliotecznymi, Dziennik Ustaw 1946, Nr 26, poz. 163. 
Nowo powstałe lub reaktywowane po wojennej zawierusze placówki biblioteczne borykały się nie tylko z problemami natury organizacyjnej, ekonomicznej i technicznej, ale przede wszystkim z brakiem wykwalifikowanej kadry. Według danych zamieszczonych w "Biuletynie Państwowego Instytutu Książki” w 1949 roku w bibliotekach publicznych i społecznych brakowało około 3000 wykwalifikowanych bibliotekarzy, natomiast $\mathrm{w}$ bibliotekach naukowych około $950^{2}$. W pierwszych powojennych latach należało więc podjacć wszelkie działania, aby jak najszybciej rozwiązać kwestię braku kadry zawodowej. Wprawdzie Biblioteka Narodowa, biblioteki uniwersyteckie oraz duże biblioteki publiczne organizowały dziesiątki kursów bibliotekarskich, które uwzględniały zróżnicowane potrzeby placówek bibliotecznych, były to jednak działania doraźne, niemogące zastąpić instytucjonalnego, systematycznego kształcenia bibliotekarzy. W 1947 roku powstała pierwsza w kraju szkoła przygotowująca młodą kadrę bibliotekarską na poziomie średnim. Było to krakowskie 2-letnie Państwowe Liceum Bibliotekarsko-Księgarskie. Warto cofnąć się o kilkadziesiąt lat i prześledzić, jak złożone były dzieje tej szkoły, tym bardziej że nie pojawiło się do tej pory ich całościowe opracowanie. Brakuje też wyczerpującego omówienia średniego szkolnictwa bibliotekarskiego lat 50. XX wieku, a publikacje na temat kształcenia bibliotekarzy jedynie wzmiankują o istnieniu liceów bibliotekarskich. Niniejszy artykuł po części wypełnia tę lukę. W jaki sposób funkcjonowało liceum bibliotekarskie w Krakowie, jaka była jego organizacja, jaki program nauczania, jaka kadra dydaktyczna - to pytania, na które starałyśmy się znaleźć odpowiedź, wykorzystując zachowane materiały archiwalne, akty prawne, wypowiedzi i wspomnienia absolwentów oraz nieliczne publikacje.

\section{Początki - Państwowe Liceum Bibliotekarsko-Księgarskie}

Inicjatorami powstania w Krakowie szkoły średniej bibliotekarsko-księgarskiej było środowisko krakowskich księgarzy i bibliotekarzy. W 1947 roku na łamach „Przeglądu Księgarskiego” Zarząd Krakowskiego Koła Związku Księgarzy Polskich zamieścił projekt organizacyjno-programowy przyszłego liceum³ ${ }^{3}$ Oprócz treści ściśle merytorycznych

${ }^{2}$ W. Nowodworski, Szkolnictwo bibliotekarskie i księgarskie, „Biuletyn Państwowego Instytutu Książki" 1949, t. 2, nr 4, s. 89.

3 Organizacja Państwowego Liceum Bibliotekarsko-Księgarskiego w Krakowie, „Przegląd Księgarski” 1947, nr 8/9, s. 181-182. 
projekt zawierał informację o przeprowadzeniu wstępnej rekrutacji celem zorientowania się w liczbie kandydatów. Do jej wykonania wyznaczono Państwowe Żeńskie Gimnazjum Handlowe w Krakowie, mieszczące się przy ul. Loretańskiej 16. Czy faktycznie takie wstępne rozpoznanie przeprowadzono, trudno dziś jednoznacznie stwierdzić. Należy jednak przypuszczać, że inicjatorzy przedsięwzięcia mieli w tym zakresie stosowną wiedzę, skoro zdecydowali się kontynuować pracę.

Decyzje wiążące, dotyczące utworzenia w Krakowie liceum bibliotekarsko-księgarskiego, zapadły 18 lutego 1947 roku podczas spotkania w Bibliotece Jagiellońskiej (BJ). Wśród zebranych obecni byli między innymi: inż. Jan Nawrocki - naczelnik Wydziału Szkół Zawodowych Kuratorium Okręgu Szkolnego w Krakowie, dr Adam Bar - pracownik BJ, dr Eustachy Gaberle - dyrektor BJ i prezes Oddziału Krakowskiego Związku Bibliotekarzy i Archiwistów Polskich, mgr Lidia Kozakówna dyrektor Państwowego Żeńskiego Gimnazjum Handlowego, Helena Lipska - pracownik BJ i kierownik kursów dla bibliotekarzy prowadzonych przez bibliotekę, dr Aleksander Słapa - dyrektor Księgarni Gebethner i Wolff, Tadeusz Zapiór - dyrektor Działu Wydawniczego Księgarni Gieszczykiewicz i właściciel wydawnictwa „Tadeusz Zapiór” w Krakowie, dr Ignacy Zarębski - dyrektor Państwowego Zakładu Wydawnictw Szkolnych i prezes Oddziału Krakowskiego Związku Księgarstwa Polskiego ${ }^{4}$. Zebrani nie mieli wątpliwości, że w Krakowie - ważnym ośrodku kulturalno-oświatowym - powinna znajdować się szkoła bibliotekarsko-księgarska na poziomie licealnym.

Efektem tego spotkania była decyzja, która zobowiązywała dyrekcję Państwowej Żeńskiej Szkoły Zawodowej do wystąpienia z pismem do Ministerstwa Oświaty o wydanie zezwolenia na otwarcie w Krakowie koedukacyjnego liceum o profilu bibliotekarsko-księgarskim. Warto dodać, że władze krakowskiego kuratorium zdecydowanie popierały inicjatywę otwarcia liceum. Na podstawie zgody Ministerstwa Oświaty ${ }^{5} 1$ września 1947 roku Państwowe Liceum Bibliotekarsko-Księgarskie w Krakowie rozpoczęło działalność.

Nauka w liceum trwała dwa lata i kończyła się egzaminem maturalnym, który uprawniał absolwentów do wstępowania do szkół wyższych. W roku szkolnym 1947/1948 do I klasy liceum przyjmowana była młodzież po ukończeniu szkoły średniej ogólnokształcącej lub zawodowej, po

${ }^{4}$ R. Ślęczka, Szkolnictwo zawodowe Krakowa w latach 1945-1961, Kraków 2003, s. 28.

${ }^{5}$ Zarządzenie z dnia 13 marca 1948 roku nr III HAG-1057/47, od dnia 1 września 1947 roku [Państwowe Liceum Bibliotekarsko-Księgarskie w Krakowie], Dziennik Urzędowy Ministerstwa Oświaty z dnia 23 kwietnia 1948 roku, poz. 82, p. 2. 
tzw. małej maturze (ukończona IX klasa). Pierwszym dyrektorem nowo powstałej szkoły został mgr Stefan Towpasz ${ }^{6}$ (ur. 1906 - zm. ?), w okresie okupacji organizator i kierownik rejonu II w Ośrodku Tajnego Nauczania nr 11 w Krakowie ${ }^{7}$, w 1946 roku nauczyciel języka polskiego w III Gimnazjum im. Króla Jana Sobieskiego w Krakowie (obecnie II Liceum im. Króla Jana III Sobieskiego w Krakowie) $)^{8}$. Następcą Towpasza na stanowisku dyrektora został dr Artur Kopacz (ur. 1884 - zm. 1962), polonista, absolwent Uniwersytetu Jagiellońskiego (UJ) oraz Uniwersytetu Jana Kazimierza we Lwowie, doświadczony nauczyciel. W okresie przedwojennym uczył w szkołach w Nowym Sączu, Trembowli, Stanisławowie, Łańcucie, Wągrowcu (poznańskie), Słupcy (łódzkie), w latach 1928-1932 był dyrektorem Państwowych Kursów Nauczycielskich we Lwowie, a następnie dyrektorem VII Gimnazjum we Lwowie (1932-1939). W okresie okupacji organizował na terenie Lwowa pomoc dla ludności żydowskiej. Po wojnie, w latach 1945-1947, pełnił funkcję kuratora Okręgu Szkolnego w Rzeszowie. 1 kwietnia 1948 roku objął stanowisko dyrektora krakowskiego liceum bibliotekarsko-księgarskiego, które sprawował do 15 września 1951 roku9

Szkoła od początku swego istnienia borykała się z poważnymi kłopotami lokalowymi. Początkowo jej siedziba mieściła się przy ul. św. Marka $37^{10}$, a następnie przy ul. Łobzowskiej $20^{11}$. Liceum miało charakter koedukacyjny, nauka odbywała się w godzinach popołudniowych, od godziny 14. Olbrzymim wyzwaniem, zarówno dla władz oświatowych, jak i dla dyrekcji, okazało się skompletowanie odpowiedniej kadry dydaktycznej, szczególnie nauczycieli przedmiotów zawodowych. Wkrótce okazało się, że zatrudnienie wszystkich nauczycieli niezbędnych do prawidłowego przebiegu procesu dydaktycznego przekracza możliwości budżetowe szkoły. Podsumowując pierwszy rok działalności liceum, dyrektor Kopacz z uznaniem podkreślił pomoc, której udzielili szkole członkowie Oddziału

${ }^{6}$ Archiwum Zakładowe Zespołu Szkół Poligraficzno-Księgarskich w Krakowie. Zaświadczenie wydane przez Państwowe Liceum Bibliotekarsko-Księgarskie w Krakowie z dnia 31 stycznia 1948 roku nr 339/48.

${ }^{7}$ J. Chrobaczyński, W. Kruczek, Nauczyciele małopolscy: portret zbiorowy 1939-1945, Kraków 2004, s. 313.

${ }^{8}$ III Gimnazjum obecnie II Liceum im. Króla Jana III Sobieskiego: 120 lat: księga pamiątkowa, red. B. Kaczkowska, Kraków [2003], s. 325.

${ }^{9}$ Polski słownik biograficzny, t. 13, Wrocław 1967-1968, s. 613-614.

10 A. Kopacz, Państwowe Liceum Bibliotekarsko-Księgarskie w Krakowie, "Przegląd Księgarski" 1948, nr 15/16, s. 229.

11 Uwiecznić czas miniony: księga jubileuszowa 100-lecia założenia szkoły 1908-2008: Zespót Szkót Poligraficzno-Księgarskich im. Zenona Klemensiewicza w Krakowie, red. A. Wnętrzak-Wnorowska, Kraków 2008, s. 35. 
Krakowskiego Związku Księgarstwa Polskiego, dofinansowując pensje nauczycieli. Nie było to jedyne wsparcie materialne ze strony związku. Młodzież ucząca się w liceum pochodziła na ogół z rodzin ubogich, kwoty zaś przeznaczone na stypendia rządowe były dalece niewystarczające i pomocą nie można było objąć wszystkich potrzebujących. Krakowscy księgarze również w tej sytuacji stanęli na wysokości zadania, fundując stypendia dla młodzieży. Dwuletni cykl edukacyjny przewidywał, że w pierwszym roku nauki wszystkie przedmioty (ogólne i zawodowe) będą wspólne zarówno dla grupy bibliotekarzy, jak i dla księgarzy. W klasie II, w siatce godzin zatwierdzonej przez Ministerstwo Oświaty, przedmioty ogólnokształcące stanowiły nadal część wspólna, natomiast przedmioty bibliotekarskie i księgarskie traktowane były oddzielnie. Oznaczało to, że uczniowie po pierwszym roku nauki powinni dokonać wyboru zawodu, aby w następnej klasie mogli uczestniczyć w odpowiedniej grupie przedmiotowej (księgarskiej lub bibliotekarskiej). W praktyce okazało się to bardzo trudne. Analizując rok szkolny 1947/1948, dyrektor Kopacz stwierdza:

[...] doświadczenia po pierwszym roku nauki wykazały, że młodzież nie umie jeszcze podjąć decyzji, gdzie w przyszłości będzie pracowała. Wypłynął stąd wniosek, że lepiej będzie, jeżeli i w drugim roku nauki młodzież ucząca się pozna praktycznie i zagadnienia bibliotekarskie, i księgarskie. Na podstawie tych doświadczeń, które doprowadziły Dyrekcję liceum do takiego przeorganizowania drugiego roku nauki - młodzież zobowiązana jest do odbycia praktyki i w księgarniach, i w bibliotekach... ${ }^{12}$.

W maju 1949 roku odbył się pierwszy egzamin maturalny i 24 absolwentów liceum opuściło mury szkolne. Grono nauczycielskie stanowili wówczas: Z. Chromińska, F. Pieczątkowski, wizytator G. Dulęba, dr T. Aschenbrenner, mgr W. Giebartowska, mgr R. Sporysz, ks. J. Werner, ks. Z. Barmiński, mgr A. Trzos, wizytator M. Kisielewska, mgr H. Lipska, dr (później prof. dr) H. Smarzyński, mgr R. Smidorowicz ${ }^{13}$. Z początkiem lat 50. nastąpiło wiele zmian personalnych. Były to bowiem lata tzw. czystek wśród kadry dydaktycznej. Na emeryturę odszedł powszechnie lubiany, ceniony i wyjątkowo oddany szkole dyrektor Kopacz, liceum opuścili także niektórzy nauczyciele. 1 września 1951 roku nowym dyrektorem została Apolonia Nyklowa (ur. 1902 - zm. ?), bardzo popierana przez krakowski aktyw partyjny, chociaż sama w projektach organizacyjnych

${ }^{12}$ A. Kopacz, op.cit., s. 228.

${ }^{13}$ Na podstawie tableau pierwszych absolwentów Państwowego Liceum Bibliotekarsko-Księgarskiego z 1949 roku. 
szkoły figuruje jako bezpartyjna. Dyrektor Nyklowa w chwili obejmowania stanowiska nie miała wymaganego przepisami wykształcenia wyższego; z zachowanych materiałów archiwalnych wynika również, że nie miała doświadczenia dydaktycznego. Dopiero w 1952 roku ukończyła (w wieku 50 lat) studia wyższe pierwszego stopnia (2-letnie) na Wydziale Filozoficzno-Społecznym UJ w zakresie nauk społecznych ${ }^{14}$. W liceum wykładała historię i naukę o konstytucji.

$\mathrm{Na}$ początku lat 50. nastąpiła kolejna zmiana siedziby szkoły. Tym razem liceum przeniesiono do Szkoły Podstawowej nr 32, mieszczącej się przy ul. Królowej Jadwigi 78. Była to wyjątkowo uciążliwa lokalizacja zarówno dla uczniów mieszkających w Krakowie, jak i dla tych, którzy dojeżdżali z okolicznych miejscowości. Biorąc pod uwagę fatalny stan ówczesnej komunikacji i znaczną odległość od centrum miasta, droga do szkoły zajmowała uczniom (a także nauczycielom) około półtorej godziny w jedną stronę. Jednakże - jak wspomina jeden $\mathrm{z}$ absolwentów liceum - dla wielu młodych ludzi

urok miały wieczorne powroty, ciemną ulicą Zwierzyniecka, zwykle zimą grzęznącą $w$ nie uprzątniętym śniegu. Ulice oświetlane były zazwyczaj jedynie czerwonymi neonami propagandowych napisów... ${ }^{15}$.

W Szkole Podstawowej nr 32 wynajmowano dziesięć sal lekcyjnych oraz jedno pomieszczenie, w którym mieściła się biblioteka.

\section{2-letnie liceum bibliotekarskie i 4-letnie liceum bibliotekarskie}

W roku szkolnym 1951/1952 nastąpiły istotne zmiany organizacyjne w funkcjonowaniu szkoły. Były one konsekwencją powołania 1 września 1951 roku Państwowego Liceum Bibliotekarskiego (4-letniego) ${ }^{16}$ oraz przekształcenia Państwowego Liceum Bibliotekarsko-Księgarskiego (2-letniego) w Państwowe Dwuletnie Liceum Bibliotekarskie ${ }^{17}$. Zmiana

${ }^{14}$ Archiwum Urzędu Miasta Krakowa, sygn. 2777/1, akta personalne nr 20.

${ }^{15}$ J. Gromnicki, Była taka szkoła..., „Salwator i Świat” 1996, nr 23, s. 4-5.

16 Zarządzenie Ministra Kultury i Sztuki z dnia 28 maja 1952 roku w sprawie utworzenia państwowych czteroletnich liceów bibliotekarskich [z mocą od 1 września 1951 roku], Monitor Polski 1952, nr A-53, poz. 787.

17 Zarządzenie nr 102 Ministerstwa Kultury i Sztuki z dnia 2 lipca 1952 roku w sprawie przemianowania Państwowego Liceum Bibliotekarsko-Księgarskiego na Państwowe 2-letnie Liceum Bibliotekarskie. 
nazewnictwa w wypadku liceum bibliotekarsko-księgarskiego nie była jedynie kwestią formalną. Wpłynęły na nią głosy środowiska krakowskich księgarzy, którzy od jakiegoś czasu mieli coraz więcej wątpliwości co do efektywności wspólnego kształcenia bibliotekarzy i księgarzy oraz postulowali utworzenie odrębnej szkoły, kształcącej wyłącznie przyszłych pracowników księgarskich. Tak się niebawem stało - 1 września 1952 roku otwarto 4-letnie technikum księgarskie, mieszczące się przy ul. Agnieszki $5^{18}$. Począwszy zatem od roku szkolnego 1951/1952, w Krakowie funkcjonowały dwie średnie szkoły bibliotekarskie. Taki stan rzeczy przetrwał do końca roku szkolnego 1953/1954, kiedy to decyzją Ministerstwa Kultury i Sztuki (MKiS) zlikwidowano Państwowe Dwuletnie Liceum Bibliotekarskie ${ }^{19}$.

Obie nowo powołane placówki szkolne miały wspólną dyrekcję i kadrę dydaktyczna, mieściły się jednak w osobnych lokalach. Liceum 4-letnie umiejscowiono przy ul. Świerczewskiego 12 (obecnie ul. Studencka 12 siedziba V Liceum Ogólnokształcącego im. Augusta Witkowskiego, a do 1956 roku VIII Państwowego Gimnazjum Matematyczno-Przyrodniczego im. Augusta Witkowskiego). W celu ułatwienia nauczycielom pracy, tak aby lekcje w obu szkołach mogły odbywać się regularnie i punktualnie, przeniesiono 2-letnie liceum z ul. Królowej Jadwigi 73 na ul. Czapskich 5, do budynku Liceum Ogólnokształcącego im. S. Konarskiego oo. Pijarów. Obie szkoły znalazły się w bliskim sąsiedztwie, co znacznie usprawniło pracę nauczycieli i dyrekcji. Na potrzeby 4-letniego liceum (ul. Świerczewskiego 12) wynajmowano siedem pomieszczeń, w tym pięć sal szkolnych na I piętrze, na parterze bibliotekę wraz z pracownią bibliotekarską i pokój nauczycielski będący równocześnie gabinetem dyrektora. Natomiast 2-letnie liceum (ul. Czapskich 5) korzystało z czterech sal na I piętrze, $\mathrm{w}$ tym $\mathrm{z}$ trzech sal lekcyjnych oraz pokoju przeznaczonego na kancelarię szkoły $^{20}$. Nauka, tak jak poprzednio, odbywała się w godzinach popołudniowych. Lekcje rozpoczynały się o godzinie 14, a kończyły najpóźniej o godzinie 21. Nie były to idealne warunki do nauki, zwłaszcza dla młodzieży dojeżdżającej spoza Krakowa, która po skończeniu lekcji docierała do domów bardzo późno, niekiedy około godziny 23.

Pierwszy nabór do 4-letniego liceum odbył się w czerwcu 1951 roku. Zgodnie ze statutem szkoły przyjmowano młodzież po 7-letniej szkole

1825 lat Technikum Poligraficzno-Księgarskiego w Krakowie Zespół Szkół Poligraficzno-Księgarskich w Krakowie, Kraków 1973, s. 11.

${ }^{19}$ Zarządzenie nr 76 Ministerstwa Kultury i Sztuki z dnia 2 maja 1954 roku w sprawie zwinięcia 2-letniego Państwowego Liceum Bibliotekarskiego w Krakowie.

${ }^{20}$ Archiwum Państwowe w Krakowie, sygn. 29/696/PWRN/KRK1 641. 
podstawowej pod warunkiem, że ukończyła 14 lat i nie przekroczyła 17 lat. Natomiast do 2-letniego liceum przyjmowano uczniów po ukończeniu IX klasy szkoły średniej ogólnokształcącej lub zawodowej (tzw. małą maturę zlikwidowano w 1948 roku). W myśl zalecenia Naczelnej Dyrekcji Bibliotek, usytuowanej w tym okresie w Ministerstwie Oświaty i sprawującej bezpośredni nadzór nad szkołami bibliotekarskimi (było ich już w kraju kilka), nabór do 2- i 4-letniego liceum propagowano przez:

- przygotowywanie referatów o znaczeniu bibliotek, które nadawano w Polskim Radiu - referatowi towarzyszyło ogłoszenie dotyczące rekrutacji,

- wygłaszanie prelekcji przez uczniów liceum (zwłaszcza aktyw ZMP) w klasach siódmych szkół podstawowych w Krakowie,

- opracowywanie konspektów, które rozsyłano do wydziałów oświaty wojewódzkich rad narodowych w całym kraju,

- sporządzanie afiszy promujących liceum i rozwieszanie ich na terenie miasta oraz w poszczególnych szkołach i bibliotekach,

- zamieszczanie ogłoszeń w prasie,

- informację przekazywaną kierownikom szkół podstawowych przez kuratoria okręgów szkolnych w poszczególnych województwach.

W Ministerstwie Oświaty została utworzona Komisja Programowa Liceów i Kursów Bibliotekarskich, której zadaniem było między innymi opiniowanie programów nauczania dla liceów bibliotekarskich. Pod koniec 1951 roku Ministerstwo Oświaty zlikwidowało Naczelną Dyrekcję Bibliotek, a jej kompetencje w zakresie bibliotek i zbiorów bibliotecznych, w tym również szkolnictwa bibliotekarskiego, przekazało Ministerstwu Kultury i Sztuki ${ }^{21}$. Bezpośredni nadzór nad liceami bibliotekarskimi sprawował od tej pory Centralny Zarząd Bibliotek, funkcjonujący w MKiS. Na szczeblu wojewódzkim instytucją odpowiedzialną za pracę liceum był Wydział Kultury Prezydium Wojewódzkiej Rady Narodowej (WK PWRN) w Krakowie. Warto podkreślić, że w odróżnieniu od większości krakowskich szkół średnich, które utrzymywane były przez władze lokalne, liceum bibliotekarskie finansowano bezpośrednio $\mathrm{z}$ budżetu centralnego MKiS. 1 lipca 1953 roku nadzór nad liceami bibliotekarskimi powierzono kolejnej instytucji sprawczej - Centralnemu Zarządowi Szkół Artystycznych MKiS.

W 1953 roku dyrektorem 2- i 4-letniego liceum nadal była Apolonia Nyklowa. Skargi płynące do WK PWRN w Krakowie ze strony Komitetu

${ }^{21}$ Ustawa z dnia 31 października 1951 roku o przekazaniu Ministrowi Kultury i Sztuki zakresu działania Ministra Oświaty w przedmiocie bibliotek i zbiorów bibliotecznych, Dziennik Ustaw R.P., nr 58, poz. 400. 
Rodzicielskiego na narastające konflikty dyrektorki z pracownikami, uczniami, rodzicami, a także coraz większe trudności w funkcjonowaniu szkoły, wynikające z wielu zaniedbań (kilkumiesięczne zaległości w opłatach za wynajmowane sale, katastrofalny stan techniczny internatu itd.), spowodowały, że Centralny Zarząd Szkół Artystycznych MKiS w kwietniu 1953 roku podjął decyzję o zwolnieniu Nyklowej z obowiązków dyrektora z dniem 31 lipca 1953 roku. Równocześnie zobowiązał ją do przygotowania rozpoczęcia roku szkolnego 1953/1954.

Pod koniec września 1953 roku WK PWRN wysunął kandydaturę mgr Ireny Lewickiej na dyrektora liceum. Kandydatka odmówiła jednak przyjęcia stanowiska. $\mathrm{W}$ okresie gdy władze zwierzchnie nie były w stanie powołać nowego dyrektora, Zespół Kontroli Oświaty i Kultury Ministerstwa Kontroli Państwowej rozpoczął szczegółową kontrolę placówki (listopad i grudzień 1953 roku). Ujawniła ona wiele nieprawidłowości w zarządzaniu szkoła, m.in. wadliwie przeprowadzoną rekrutację, niewykorzystywanie przyznanych kredytów na zakup pomocy naukowych, nieprawidłowości w preliminarzu budżetowym praktyk wakacyjnych (z tego powodu praktyka wakacyjna nie odbyła się), brak zatwierdzenia rocznego planu dydaktyczno-wychowawczego i planów odcinkowych. Stwierdzono również, że bogaty księgozbiór szkoły (w 1953 roku liczący 7471 woluminów) nie jest należycie wykorzystywany, a poziom czytelnictwa wśród uczniów - przyszłych bibliotekarzy - zaskakująco niski. Podczas wizytacji zwrócono uwagę na fakt, że dyrektor Nyklowa nie przeprowadzała żadnych hospitacji lekcji, co w znacznym stopniu przyczyniło się do słabych wyników nauczania. Potwierdzono, zgłoszony wcześniej przez Komitet Rodzicielski, brak należytego nadzoru w godzinach popołudniowych i nocnych nad młodzieżą mieszkającą w internacie szkoły. Zastrzeżenia dotyczyły również wynagrodzenia dyrektorki (nadmierna liczba godzin nadliczbowych, pobieranie podwójnego dodatku funkcyjnego). Jak widać, Nyklowa nie zapewniała szkole zarządzania na dobrym poziomie, a mimo to pozostała na stanowisku dyrektora aż do kwietnia 1954 roku, a jako nauczyciel etatowy 4-letniego liceum do końca roku szkolnego 1953/1954. W wyniku kilkumiesięcznej procedury odwoławczej ostateczne odejście Nyklowej ze szkoły nastąpiło 1 lutego 1955 roku $^{22}$.

Następnym, i zarazem ostatnim, dyrektorem Państwowego Liceum Bibliotekarskiego w Krakowie została w maju (lub z końcem kwietnia) 1954 roku Wanda Dżugan (ur. 1906 - zm. ?), z wykształcenia magister historii i historii sztuki. W chwili obejmowania stanowiska była

${ }^{22}$ Archiwum Urzędu Miasta Krakowa, sygn. 2777/1, akta personalne nr 20. 
równocześnie nauczycielką w Państwowym Liceum Sztuk Plastycznych w Krakowie. Funkcję swą sprawowała aż do momentu zamknięcia szkoły w 1960 roku $^{23}$. W liceum bibliotekarskim uczyła historii w klasach maturalnych. Był to, wydaje się, najspokojniejszy okres funkcjonowania liceum, choć nie pozbawiony kłopotów. Przykładowo w sierpniu 1954 roku, tuż przed rozpoczęciem nowego roku szkolnego, dyrekcja VIII Państwowego Gimnazjum Matematyczno-Przyrodniczego im. Augusta Witkowskiego wypowiedziała z dniem 31 sierpnia 1954 roku lokal zajmowany dotychczas przez liceum. Powodem takiej decyzji było niewykonanie remontu wynajmowanych sal, mimo przyznanych na ten cel przez MKiS kwot kredytowych. Ostatecznie konflikt zażegnano i liceum do ostatniego dnia mieściło się przy ul. Świerczewskiego 12. Pomijając trudności lokalowe, największymi problemami zarówno 2-, jak i 4-letniego liceum było to, że zmieniające się co pewien czas instytucje odpowiedzialne za ich działalność w znikomym stopniu przyczyniały się do doskonalenia ich pracy. W zakresie przedmiotów zawodowych szkoły realizowały program tymczasowy, a powołana do opracowania programów nauczania Komisja Programowa nigdy nie wywiązała się z powierzonego jej zadania. Brak podręczników do przedmiotów zawodowych dodatkowo utrudniał pracę i nauczycielom, i uczniom.

\section{Grono pedagogiczne}

Z zachowanych materiałów archiwalnych wynika, że zespół nauczycieli zarówno w 2-, jak i w 4-letnim liceum nie był stabilny. Grono pedagogiczne liczyło 20-26 osób (liczba ta zmieniała się w zależności od liczby oddziałów w poszczególnych latach), wśród których na ogół wszyscy mieli wykształcenie wyższe. Nauczyciele zatrudniani byli jako pracownicy etatowi, pracownicy kontraktowi pełnozatrudnieni oraz pracownicy kontraktowi zatrudnieni w wymiarze niepełnym. Przykładowo w roku szkolnym 1951/1952 liceum zatrudniało 21 pedagogów, w tym tylko czterech nauczycieli w pełnym wymiarze godzin, pozostałych, etatowo związanych z innymi szkołami, zatrudniano na kilka godzin nauki ${ }^{24}$. Natomiast według danych za rok szkolny 1956/1957 w szkole pracowało sześciu nauczycieli etatowych, czterech kontraktowych pełnozatrudnionych oraz 12 kontraktowych zatrudnionych $w$ wymiarze niepełnym ${ }^{25}$. Grono

\footnotetext{
${ }^{23}$ Ibidem, akta nr 44 - Dyrekcja Liceum - korespondencja.

${ }^{24}$ Ibidem, wykaz pracowników pedagogicznych za rok szkolny 1951/1952.

${ }^{25}$ Ibidem, wykaz pracowników pedagogicznych za rok szkolny 1956/1957.
} 
pedagogiczne składało się z nauczycieli przedmiotów ogólnokształcących i przedmiotów zawodowych.

Pracujący w szkole nauczyciele przedmiotów ogólnokształcących byli dobrze przygotowani do swoich obowiązków. Oprócz wykształcenia wyższego niemal wszyscy mieli złożone egzaminy, które uprawniały ich do nauczania w szkołach średnich. Byli to więc nauczyciele o pełnych kwalifikacjach i przeważnie z długoletnim doświadczeniem dydaktycznym. Niektórzy z nich pracowali w liceum niemal przez cały okres jego istnienia. Część pedagogów ukończyła dodatkowo kursy bibliotekarskie. Do tych, którzy najdłużej pracowali, należeli między innymi: mgr Zofia Weigt $^{26}$, absolwentka filologii klasycznej, w latach 1949-1960 nauczycielka języka łacińskiego, francuskiego i niemieckiego, mgr Maria Łuczyńska absolwentka Uniwersytetu Jana Kazimierza we Lwowie i UJ, w latach 1953-1960 uczyła matematyki i chemii, mgr inż. Maria Mazurek, absolwentka Wydziału Rolniczego UJ, w latach 1952-1960 nauczycielka fizyki i chemii, mgr Maria Porębska, w latach 1952-1959 nauczycielka matematyki, mgr Kazimierz Krasnowolski, w latach 1953-1959 uczył biologii, mgr Janina Grysowska, nauczycielka wychowania fizycznego w latach 1952-1960, oraz dr Maria Peter, absolwentka Uniwersytetu Jana Kazimierza we Lwowie, w latach 1950-1960 nauczycielka języka polskiego i historii, przez pewien okres pełniła również funkcję zastępcy dyrektora szkoły.

Wśród nauczycieli przedmiotów ogólnych występowała duża fluktuacja kadry. Nauczyciele bardzo często byli przenoszeni do innych szkół po jednym, dwóch miesiącach pracy z zupełnie niewiadomych powodów. Kuriozalny z dzisiejszej perspektywy, ale chyba typowy dla lat 50 . sposób przechodzenia niektórych nauczycieli w obrębie krakowskich szkół średnich ilustruje przykład polonistki mgr Ireny Lewickiej ${ }^{27}$. Decyzją WK PWRN w Krakowie została zwolniona z obowiązków etatowego nauczyciela w Państwowym Liceum Muzycznym im. Fryderyka Chopina w Krakowie i zobowiązana do objęcia nowych obowiązków służbowych w Państwowym Liceum Bibliotekarskim od 1 września 1953 roku. Lewicka pracowała w liceum jako nauczycielka języka polskiego do końca funkcjonowania szkoły.

W tajniki zawodu bibliotekarza wprowadzali uczniów uznani w środowisku krakowskim bibliotekarze i księgarze. W latach 1947-1952 byli to między innymi: Genowefa Dulęba, Feliks Pieczątkowski, Maria

${ }^{26}$ Ibidem, akta personalne kolejno $\mathrm{nr}$ 38, 19, 20, 25, 13, 9, 24 (nauczyciele przedmiotów ogólnych).

${ }^{27}$ Ibidem, pismo WK PWRN z dnia 11 lipca 1953 roku. 
Kisielewska, dyrektor Artur Kopacz oraz doc. dr Józef Korpała. Józef Korpała (1905-1989) był wybitnym bibliologiem i teoretykiem bibliografii, organizatorem i dyrektorem (1946-1975) Miejskiej Biblioteki Publicznej w Krakowie, pracownikiem naukowym UJ i Wyższej Szkoły Pedagogicznej. Opublikował ponad 700 artykułów i książek, w tym m.in.: Zarys dziejów bibliografii w Polsce (Wrocław 1953), Dzieje bibliografii w Polsce (Warszawa 1969), O bibliografiach i informatorach (Warszawa 1974), Karol Estreicher (st.) twórca "Bibliografii Polskiej” (Wrocław 1980). W 1982 roku UJ odnowił mu doktorat (forma doktoratu honoris causa dla absolwentów tej samej uczelni). W liceum bibliotekarskim Korpała prowadził zajęcia z pedagogiki bibliotecznej ${ }^{28}$.

Począwszy od roku szkolnego 1954/1955, trzon kadry nauczającej przedmiotów zawodowych stanowiło czterech nauczycieli - Genowefa Dulęba (nauczycielka etatowa) oraz Stanisław Stochel, Tadeusz Zapiór i mgr Edward Chełstowski (zatrudnieni w wymiarze niepełnym). Ponadto metodyki pracy z czytelnikiem uczyła mgr Irena Lewicka (etatowa nauczycielka języka polskiego) oraz Maria Kisielewska, kierownik referatu bibliotek w WK PWRN w Krakowie. W wykazie pracowników z roku szkolnego 1956/1957 Stanisław Stochel figuruje już jako nauczyciel etatowy, w tym więc okresie liceum miało dwóch etatowych nauczycieli przedmiotów zawodowych oraz czterech kontraktowych zatrudnionych w niepełnym wymiarze godzin ${ }^{29}$.

Przez cały okres istnienia szkoły głównym filarem grona pedagogicznego w zakresie kształcenia zawodowego była Genowefa Dulęba ${ }^{30}$ (Dulębina, ur. 1904 - zm. 1980). W chwili podjęcia pracy w Państwowym Liceum Bibliotekarsko-Księgarskim w 1947 roku była równocześnie kierownikiem referatu bibliotek w Kuratorium Okręgu Szkolnego w Krakowie (1945-1950) i prowadziła wykłady z zakresu organizacji bibliotek powszechnych w krakowskiej Wyższej Szkole Nauk Społecznych. Zatrudniona początkowo w charakterze nauczyciela kontraktowego, szybko została nauczycielem etatowym (po odejściu z kuratorium). W liceum prowadziła zajęcia z bibliotekarstwa, bibliotekoznawstwa i metodyki pracy z czytelnikiem. Opiekowała się też szkolną biblioteka, pracownią bibliotekarską, a także całością prac związanych z praktykami uczniowskimi. Była nieformalnym zastępcą dyrektora szkoły w latach 1947-1954. W pracy dydaktycznej wykorzystywała

${ }^{28}$ H. Fleszar, Józef Korpała (1905-1989): bibliografia podmiotowo-przedmiotowa w wyborze, Kraków 1999, s. 9.

${ }^{29}$ Archiwum Urzędu Miasta Krakowa, sygn. 2777/1, Wykaz pracowników pedagogicznych i administracyjnych za rok szkolny 1956/1957.

${ }^{30}$ Ibidem, akta personalne nr 3. 
wiedzę z zakresu bibliotekarstwa zdobytą w Studium Pracy Społeczno-Oświatowej Wolnej Wszechnicy Polskiej w Warszawie pod kierunkiem Heleny Radlińskiej (1927-1929) oraz własne przedwojenne doświadczenie wieloletniej działaczki społeczno-oświatowej, nauczycielki, kierowniczki Biblioteki Powiatowej w Będzinie, organizatorki szkoleń dla bibliotekarzy i inicjatorki reorganizacji bibliotek oświatowych w Zagłębiu Dąbrowskim, wreszcie instruktorki do spraw bibliotekarstwa i czytelnictwa w okręgu krakowskim. Po rozwiązaniu liceum kontynuowała działalność zawodową kierując Działem Sieci w Miejskiej Bibliotece Publicznej w Krakowie ${ }^{31}$. Prowadziła też wykłady w Wyższej Szkole Pedagogicznej w Krakowie.

W latach 1954-1960 nauczycielem bibliografii i pedagogiki bibliotecznej był mgr (od 1962 roku dr) Edward Chełstowski ${ }^{32}$ (ur. 1913 - zm. 2001), w latach 1949-1952 dyrektor nowo zorganizowanej Wojewódzkiej Biblioteki Publicznej w Krakowie, a następnie pracownik BJ (kierownik Oddziału Magazynów i Konserwacji Zbiorów oraz kierownik Oddziału Dokumentów Życia Społecznego). Podczas wielu spotkań z bibliotekarzami wielokrotnie podkreślał, że należy wzmacniać i rozwijać szkoły bibliotekarskie. Dzięki niemu eksponaty ze zbiorów BJ wykorzystywano do pokazów przy nauczaniu poszczególnych przedmiotów, dublety biblioteczne służyły jako materiały do ćwiczeń z bibliografii, a młodzież wielokrotnie mogła zwiedzać BJ. Po zakończeniu pracy w liceum kontynuował działalność bibliotekarską i pracę dydaktyczną jako dyrektor Biblioteki Głównej Wyższej Szkoły Pedagogicznej w Krakowie i nauczyciel akademicki na kierunku bibliotekoznawstwo i informacja naukowa na tejże uczelni.

Przedmiot nauka o książce i bibliotece wykładał w latach 1951-1958 wybitny księgarz i wydawca, absolwent UJ - Tadeusz Zapiór ${ }^{33}$ (ur. 1899 zm. 1988). Od 1928 roku pracował jako księgarz w firmie Gebethnera i Wolffa w Krakowie, po wojnie prowadził własną firmę księgarsko-wydawniczą „Wiedza-Zawód-Kultura T. Zapiór”. Pracował też w Krakowskim Wydawnictwie Naukowym i współpracował z wydawnictwem Ossolineum. Wydał kilka pozycji z dziedziny księgarstwa oraz wiele książek dla dzieci. Przetłumaczył z języka niemieckiego i opatrzył uzupełnieniami Dzieje ksiażki Svenda Dahla (1965). Aktywnie uczestniczył w pracach organizacji społecznych księgarzy i wydawców. Warto przypomnieć, że Tadeusz Zapiór należał do grona współorganizatorów Państwowego Liceum Bibliotekarsko-Księgarskiego w Krakowie.

31 Pracownicy Wojewódzkiej Biblioteki Publicznej w Krakowie w latach 1945-2005, oprac. I. Górny, M. Kietlińska-Kamińska, Kraków 2005, s. 35.

32 Słownik pracowników książi polskiej. Suplement III, Warszawa 2010, s. 39.

${ }^{33}$ Stownik pracowników ksią̇ki polskiej. Suplement II, Warszawa 2000, s. 184-185. 
W latach 1954-1959 wykładowcą przedmiotu nauka o książce był również Stanisław Stochel ${ }^{34}$ (ur. 1909 - zm. 1997). W latach 1935-1950 był kierownikiem Szkoły Podstawowej w Kwaczale (wieś w województwie małopolskim, w gminie Alwernia), gdzie reaktywował publiczną bibliotekę gromadzka, założoną w 1860 roku przez Józefa Patelskiego. W 1951 roku objął stanowisko zastępcy dyrektora Wojewódzkiej Biblioteki Publicznej w Krakowie, które zajmował do 1964 roku. W liceum bibliotekarskim, oprócz obowiązków ściśle dydaktycznych, nieformalnie pełnił funkcję zastępcy dyrektora, kierując zespołem nauczycieli przedmiotów zawodowych, nadzorując praktyki uczniowskie oraz uczestnicząc w Komisji Przydziału Pracy dla Absolwentów. Był uznanym społecznikiem. Z jego inicjatywy w 1959 roku powstał Społeczny Komitet Budowy Bibliotek, który dofinansował budowę dziesięciu bibliotek publicznych. Pracę dydaktyczną kontynuował w Policealnym Ośrodku Korespondencyjnego Kształcenia Bibliotekarzy.

Nauczyciele przedmiotów zawodowych doskonalili swój warsztat dydaktyczny i uzupełniali wiedzę merytoryczną na corocznych wakacyjnych wyjazdowych kursokonferencjach (6-14 dni), organizowanych dla dyrektorów liceów bibliotekarskich i nauczycieli zawodu (m.in. w Zakopanem, Orłowie). Brali udział w konferencjach dla nauczycieli szkół bibliotekarskich z udziałem wizytatorów okręgowych nadzorujących te szkoły oraz dyrektorów bibliotek wojewódzkich i miejskich. Uczestniczyli w szkoleniach organizowanych przez Centralny Zarząd Szkół Artystycznych MKiS, jako uczestnicy lub w charakterze prelegentów ${ }^{35}$.

\section{Programy nauczania}

Założeniem programowym 2-letniego Państwowego Liceum Bibliotekarsko-Księgarskiego było przygotowanie uczniów do pracy w bibliotekach i księgarniach. Jak wspomniano, w klasie II naukę podzielono na dwie grupy przedmiotowe - bibliotekarską i księgarską. Analizując wykaz przedmiotów na świadectwach maturalnych absolwentów z lat 1949, 1950, 1951, można z całą pewnością stwierdzić, że w praktyce nie udało się spełnić tego założenia; świadectwa nie uwzględniają specjalizacji. Uczniowie realizowali wspólny program w zakresie przedmiotów ogólnokształcących i zawodowych.

\footnotetext{
${ }^{34}$ Pracownicy Wojewódzkiej Biblioteki Publicznej..., s. 14.

35 Archiwum Państwowe w Krakowie, sygn. 29/696/PWRN/KRK1 905, 29/696/ PWRN/KRK1 907.
} 
Przedmioty ogólnokształcące obejmowały: literaturę polską język polski, dwa języki obce nowożytne, język łaciński, historię z nauką o Polsce i świecie współczesnym, prawoznawstwo, matematykę. Wśród przedmiotów zawodowych wyróżnić można: historię książki, bibliotek i księgarstwa, morfologię i produkcję książki, bibliografię, bibliotekoznawstwo i bibliotekarstwo, księgarstwo, czytelnictwo, grafikę użytkową oraz konserwację książki (introligatorstwo). Uczniowie mieli poza tym zajęcia z takich przedmiotów jak: arytmetyka handlowa i księgowość, technika pracy umysłowej, biurowość i korespondencja. Od 1951 roku, w wyniku zmian organizacyjnych, szkoła przygotowywała wyłącznie przyszłych bibliotekarzy w cyklu 2- i 4-letnim. W 1952 roku do egzaminu dojrzałości pierwszy raz przystąpili abiturienci 2-letniego liceum. W związku ze zmianą profilu kształcenia zniknęły z programu przedmioty księgarskie, natomiast na świadectwach widnieją takie przedmioty bibliotekarskie jak: nauka o książce, bibliografia, bibliotekoznawstwo, bibliotekarstwo, pedagogika biblioteczna i higiena zawodu bibliotekarskiego. Do programu włączono również praktykę biblioteczną i lekcje pisania na maszynie. W zakresie przedmiotów ogólnych obowiązywał program X i XI klasy szkoły ogólnokształcącej.

4-letnie liceum wykształciło sześć roczników bibliotekarzy (kończyli oni naukę kolejno w latach 1955-1960). Realizowano program VIII, IX, X i XI klasy szkoły ogólnokształcącej, z uwzględnieniem zmian spowodowanych wprowadzeniem przedmiotów zawodowych. Program nauczania przedmiotów bibliotekarskich ustalało każdorazowo MKiS, natomiast program nauczania przedmiotów ogólnokształcących był konsultowany z Ministerstwem Oświaty ${ }^{36}$. Wykaz przedmiotów zawodowych wraz $\mathrm{z}$ liczbą godzin przedstawia poniższe zestawienie:

- nauka o książce i bibliotece - klasa I - 1 godz./tydz., klasy II i III 2 godz./tydz.,

- bibliotekarstwo - klasy I-IV - 2 godz./tydz.,

- bibliografia - klasy II i III - 2 godz./tydz.,

- metodyka pracy z czytelnikiem w bibliotece i świetlicy - klasy I i II 4 godz./tydz., klasa IV - 2 godz./tydz.,

- pedagogika biblioteczna - klasa IV - 2 godz./tydz.,

- praktyka biblioteczna - klasy II i III - 4 godz./tydz., klasa IV 2 godz./tydz.,

- zajęcia w bibliotece - rysunek zawodowy - klasy I i II - 2 godz./tydz.

36 Zarządzenie Ministra Kultury i Sztuki z dnia 28 maja 1952 roku w sprawie utworzenia państwowych czteroletnich liceów bibliotekarskich [z mocą od 1 września 1951 roku], Monitor Polski 1952, Nr A-53, poz. 787. 
Na uwagę zasługuje fakt, że w liceum szczególne znaczenie miało nie tylko kształcenie zawodowe. Dużą wagę przywiązywano do nauki języków obcych. Wszyscy słuchacze uczyli się łaciny, języka rosyjskiego i języka zachodniego (angielskiego, francuskiego lub niemieckiego). Drugi język nowożytny wycofano z programu pod koniec funkcjonowania szkoły ${ }^{37}$.

\section{Praktyki zawodowe}

Praktyka zawodowa, jedna z form przygotowania zawodowego młodzieży, zmieniała się na przestrzeni lat. W liceum bibliotekarsko-księgarskim obowiązywała miesięczna praktyka wakacyjna po ukończeniu klasy I. Od 1951 roku praktyka w 2- i 4-letnim liceum bibliotekarskim prowadzona była zarówno w szkole, jak i poza jej siedzibą. W 2-letnim liceum uczniowie w ciągu roku (październik-luty) odbywali dwutygodniową praktyczną naukę zawodu w szkolnej pracowni bibliotekarskiej i w bibliotece, a następnie dwutygodniowe przeszkolenie $\mathrm{w}$ wybranych bibliotekach na terenie całego kraju (marzec).

W 4-letnim liceum praktykę bibliotekarską organizowano według następujących zasad. Uczniowie po ukończeniu klasy I realizowali tzw. plan zwiedzeń, który obejmował:

- zwiedzenie dwóch dowolnie wybranych przez siebie bibliotek,

- zwiedzenie w czasie ferii letnich biblioteki publicznej powiatowej, gminnej i punktu bibliotecznego oraz wykazanie się pracą społeczną (około 20 godz.) w dowolnie wybranej bibliotece,

- grupowe zwiedzanie wybranych bibliotek.

Klasa II odbywała dwutygodniową praktykę śródroczną (październik-luty) w bibliotece szkolnej i w pracowni bibliotekarskiej. Trwała ona 10 dni, po trzy godziny dziennie (30 godz.), w czasie których młodzież zapoznawała się z organizacją księgozbioru w bibliotece i techniką wypożyczania książek. Praktykę klasy III organizowano na podobnych zasadach jak praktykę klasy II, z tym że trwała ona 12 dni, po cztery godziny dziennie (48 godz.), a jej celem było zapoznanie uczniów z opracowaniem księgozbioru, praktyką udostępniania (wypożyczalnia, czytelnia) oraz organizowaniem różnego typu imprez bibliotecznych, w tym wystaw. Zajęcia odbywały się w sześcioosobowych grupach. Uczniowie klas II i III mieli również obowiązek zaliczenia dwutygodniowej praktyki w wyznaczonych bibliotekach. Zgodnie z zaleceniem Centralnego

\footnotetext{
${ }^{37}$ Archiwum Urzędu Miasta Krakowa, sygn. 2771/1 i 2771/3.
} 
Zarządu Bibliotek MKiS z 1952 roku program praktyk powinien obejmować następującą tematykę:

- zagadnienia organizacji i techniki prowadzenia biblioteki, w tym prowadzenie statystyki, sprawozdawczości, planowania i budżetu,

- formy pracy z czytelnikiem (wypożyczalnia, czytelnia, spotkania z czytelnikami),

- zapoznanie młodzieży ze zdobyczami racjonalizatorstwa i ze współzawodnictwem,

- udział w zebraniach produkcyjnych na terenie biblioteki.

Uczniowie podczas praktyki prowadzili dzienniczki praktyk, w których notowali wykonywane czynności. Dodatkowym rezultatem szkolenia było opracowanie referatu na temat organizacji biblioteki, w której przebywali. Referat przedkładany był nauczycielowi kierującemu praktykami. Ocenę wykonywanych czynności oraz ocenę postawy praktykanta dyrekcja biblioteki przesyłała na adres szkoły listownie. Od 1956 roku obowiązywała miesięczna praktyka wakacyjna (chłopcy - lipiec, dziewczęta - sierpień). Szkolenia odbywały się w wyznaczonych bibliotekach miejskich i powiatowych na terenie województwa krakowskiego, po dwie, trzy lub pięć osób w poszczególnych placówkach. Organizację praktyk koordynował WK PWRN - Samodzielny Referat Bibliotek w Krakowie. Przy wyborze placówek zwracano uwagę przede wszystkim na możliwość zapewnienia młodzieży odpowiedniej opieki zawodowo-wychowawczej oraz względnie dogodnego zakwaterowania i wyżywienia ${ }^{38}$.

\section{Młodzież szkolna}

Kandydaci do liceum rekrutowali się przeważnie z Krakowa i z województwa krakowskiego, ale byli wśród nich także mieszkańcy na przykład Poznania, Warszawy, Łodzi. Szkoła miała charakter koedukacyjny, przeważały dziewczęta. Uczniom spoza Krakowa zapewniano miejsce w internacie szkolnym, mieszczącym się przy ul. Augustiańskiej 7. Do 1952 roku młodzież korzystała z bezpłatnego wyżywienia i państwowych dopłat na wyżywienie $\mathrm{w}$ internacie. Uczniowie o niskich dochodach otrzymywali stypendia.

Ministerstwo Oświaty, a od 1951 roku MKiS, corocznie ustalało limity naboru do poszczególnych klas. Chętnych było zazwyczaj więcej, niż przewidywał limit. Przykładowo, w roku szkolnym 1952/1953

38 Archiwum Państwowe w Krakowie, sygn. 29/696/PWRN/KRK1 904, 29/696/ PWRN/KRK1 907, 29/696/PWRN/KRK1 641. 
limit wynosił 180 osób: dwa oddziały klas I - po 40 uczniów - w liceum 2-letnim, dwa oddziały klas I - po 50 uczniów - w liceum 4-letnim. W wyniku rekrutacji przyjęto jednak 217 uczniów. Klasy były bardzo liczne, co z pewnością nie ułatwiało procesu dydaktycznego. Nauczyciele niejednokrotnie podkreślali słaby poziom przygotowania młodzieży wyniesiony ze szkoły podstawowej, zwłaszcza z języka polskiego i matematyki. Zdarzało się, że uczniowie nie potrafili płynnie czytać. W liceum działało w związku z tym kilka kół samokształceniowych niosących pomoc w nauce słabszym uczniom. Zajęcia obejmowały następujące przedmioty: matematykę (2 godz./tydz.), język polski (3 godz./tydz.), fizykę (2 godz./tydz.), język rosyjski (2 godz./tydz.). Nie było tego problemu w liceum 2-letnim, które pracowało na podbudowie klasy VIII i IX szkoły średniej. Efektywność nauczania, wyznaczona różnicą między liczbą uczniów rozpoczynających a liczbą uczniów kończących naukę, kształtowała się odmiennie w poszczególnych latach; więcej uczniów odpadało jednak w 4-letnim liceum - ponad 30\%. Poniższe tabele przedstawiają liczbę uczniów, którzy ukończyli 2- i 4-letnie liceum w poszczególnych latach.

Tabela 1. Uczniowie kończący 2-letnie liceum w latach 1949-1954

\begin{tabular}{|c|c|c|}
\hline Rok szkolny & $\begin{array}{c}\text { Rok egzaminu } \\
\text { maturalnego }\end{array}$ & Liczba uczniów zdających maturę i kończących liceum \\
\hline $1948 / 1949$ & 1949 & 24 (jedna klasa) \\
\hline $1949 / 1950$ & 1950 & II a -43, II $b-39$ \\
\hline $1950 / 1951$ & 1951 & II a -43, II $b-40$ \\
\hline $1951 / 1952$ & 1952 & II a -39, II b - 36 \\
\hline $1952 / 1953$ & 1953 & brak danych \\
\hline $1953 / 1954$ & 1954 & 25 (jedna klasa) \\
\hline
\end{tabular}

Źródło: Archiwum Urzędu Miasta Krakowa, sygn. 2771/1 (akta Dyrekcji Liceum), 2771/3 (świadectwa dojrzałości, protokoły egzaminu dojrzałości za lata 1949-1960).

Tabela 2. Uczniowie kończący 4-letnie liceum w latach 1955-1960

\begin{tabular}{|c|c|c|}
\hline Rok szkolny & $\begin{array}{c}\text { Rok egzaminu } \\
\text { maturalnego }\end{array}$ & Liczba uczniów zdających maturę i kończących liceum \\
\hline $1954 / 1955$ & 1955 & IV a -28, IV b - 23 \\
\hline $1955 / 1956$ & 1956 & IV a -28, IV b - 22, IV c - 18 \\
\hline $1956 / 1957$ & 1957 & IV a - 23, IV b - 21 \\
\hline $1957 / 1958$ & 1958 & IV a -21, IV b - 18 \\
\hline $1958 / 1959$ & 1959 & 24 (jedna klasa) \\
\hline $1959 / 1960$ & 1960 & IV a -29, IV b - 21 \\
\hline
\end{tabular}

Źródło: Archiwum Urzędu Miasta Krakowa, sygn. 2771/1 (akta Dyrekcji Liceum), 2771/3 (świadectwa dojrzałości, protokoły egzaminu dojrzałości za lata 1949-1960). 
Warto dodać, że uczniowie kończący szkołę na ogół wykazywali się niezłymi wynikami w nauce; na świadectwach maturalnych przeważają oceny dobre i bardzo dobre. Corocznie Komisja Rekrutacyjna kierowała najlepszych absolwentów na wyższe uczelnie. Obowiązywał limit wynoszący 10\% ogólnej liczby uczniów w danej klasie. W liceum działała także Komisja Przydziału Pracy (obowiązywał tzw. nakaz pracy), która kierowała absolwentów do pracy w bibliotekach miejskich i powiatowych w całej Polsce, a także w innych instytucjach, np. urzędach państwowych lub domach kultury.

\section{Organizacje szkolne i działalność pozalekcyjna}

Przywiązywano dużą wagę do udziału młodzieży w organizacjach szkolnych. Ich celem było współtworzenie programu wychowawczego szkoły, kształtowanie umiejętności zespołowego działania, wyzwalanie aktywności społecznej, organizowanie działalności kulturalnej, oświatowej i sportowej. Uczniowie należeli do: Samorządu Szkolnego, Związku Młodzieży Polskiej, Koła Wszechnicy Radiowej, Szkolnego Koła PCK, Szkolnego Koła Odbudowy Warszawy, Koła Ligi Przyjaciół Żołnierza, Szkolnego Koła Towarzystwa Przyjaźni Polsko-Radzieckiej, Szkolnego Koła Sportowego "Zryw” (dziewięć sekcji sportowych). Ponadto uczestniczyli w zajęciach świetlicowych, podczas których przygotowywano akademie, wieczornice, występy artystyczne, omawiano sztuki teatralne przed wyjściem do teatru, urządzano gry i konkursy (szarady książkowe, zagadki literackie, inscenizacje tytułów książek itp.), wykonywano gazetki ścienne. Młodzież chętnie pomagała w szkolnej bibliotece, wykonując rozmaite prace, niekiedy bardzo specjalistyczne, takie jak oprawy introligatorskie książek i czasopism. Uczniowie brali udział w uroczystościach szkolnych, imprezach środowiskowych, akcjach na rzecz środowiska lokalnego (np. pomagali przy organizowaniu biblioteki w Nowej Hucie). Odbywali wycieczki do bibliotek, zakładów graficznych, a w ramach programu turystycznego - wycieczki krajoznawcze ${ }^{39}$.

\section{Likwidacja szkoły}

W ciagu 13 lat istnienia liceum bibliotekarskiego w Krakowie mury szkolne opuściło około 600 absolwentów (brak danych z roku 1952/1953).

${ }^{39}$ Archiwum Państwowe w Krakowie, sygn. 29/696/PWRN/KRK1 906. 
Decyzję o zamknięciu liceów bibliotekarskich podjęło MKiS na podstawie wyników badań przeprowadzonych przez Instytut Książki i Czytelnictwa, dotyczących stanu zatrudnienia absolwentów i ich przygotowania do pracy. Badania wykazały, że absolwenci liceów w znacznym procencie nie podejmowali pracy w zawodzie bibliotekarskim, a wyniesiona ze szkoły wiedza była nazbyt teoretyczna, bez podłoża praktycznego. Podkreślano również słabe przygotowanie do pracy z czytelnikiem, brak zamiłowania do zawodu i niedocenianie jego wartości ${ }^{40}$.

Trudno do końca zgodzić się z tymi argumentami. Absolwenci podejmowali przecież zatrudnienie zgodnie z nakazem pracy - dopiero po dwóch latach mieli prawo innego wyboru. Potem nie wszyscy pozostawali $\mathrm{w}$ zawodzie, ale też warunki pracy i płacy w bibliotekach nie zachęcały ich do tego. Z dzisiejszej perspektywy nie dziwi fakt, że młodzi ludzie dokonywali własnych wyborów drogi zawodowej. Wielu z nich wykorzystało, od razu lub później, szansę kontynuowania nauki na wyższych uczelniach, wielu też po ukończeniu studiów powracało do pracy w bibliotekarstwie, niejednokrotnie zajmując stanowiska kierownicze (dyrektorzy bibliotek, kierownicy oddziałów). Wątpliwości wzbudza także stwierdzenie, że absolwenci byli słabo przygotowani do pracy zawodowej. Nie było tak w przypadku liceum bibliotekarskiego w Krakowie. Należy podkreślić, że szkoła kładła nacisk na jakość nauczania w zakresie zarówno teorii, jak i praktyki. Na uwagę zasługuje również fakt, że to tu wykuwały się nowatorskie metody nauczania, tu przeprowadzano próby i eksperymenty, tu ustalano programy pracy. Absolwenci, których sporo pracowało w rozmaitych bibliotekach Krakowa i województwa krakowskiego (w samej Bibliotece Głównej Akademii Górniczo-Hutniczej oraz w bibliotekach sieci uczelnianej - 14 osób), dali się poznać jako osoby dysponujące odpowiednią wiedzą zawodową i bardzo zaangażowane w swoją pracę; wśród nich byli także prawdziwi pasjonaci swego zawodu.

\footnotetext{
${ }^{40}$ S. Antoszczuk, Kształcenie bibliotekarzy w Polsce w latach 1949-1970 i ich zatrudnienie, „Rocznik Biblioteki Narodowej” R. 7, 1971, s. 12 - autor, wskazując przyczynę likwidacji liceów bibliotekarskich, dodaje, że w latach 1952-1957 wykształciły one łącznie 537 absolwentów, co wydaje się ewidentną pomyłka, biorąc pod uwagę liczbę absolwentów w samym tylko liceum krakowskim (około 600).
} 
MAŁGORZATA DUDZIAK-KOWALSKA, BARBARA JANCZAK

\title{
Some material relating to the history of librarianship secondary schools. The case example of the librarianship school in Cracow (1947-1960)
}

\begin{abstract}
Aвstract. In the period shortly after the WWII, secondary schools in librarianship had a substantial part in the education of future library staff for libraries. The present article attempts to provide an insight into this particular period with the case example provided by the Cracow-based Liceum Bibliotekarskie (library specialized high school in the Polish educational system). The evaluation is mainly based on available archival material. The following aspects of the functioning of the school are discussed: creation, initial organization and management of the school, supervision within the structure of national educational system and the reasons behind its dissolution. In addition, core curricula, the school's staff and the quality of education are discussed, as well as brief profiles of its pupils and graduates are provided. The article also presents brief profiles of the school's directors and distinguished teachers. Though it is hard to say that the overall performance of the school can be unequivocally summarized, its merits and contribution to the educational system at the times of post-war scarcity of qualified librarians can hardly be overlooked. It should be believed that the present humble contribution of the present authors to the general study on the history of librarianship schools in Poland will stimulate other researchers to take on further research on the subject and formulate more in-depth analyses.
\end{abstract}

KEY wORDs: education of librarians, secondary librarianship schools, specialized lyceum for librarians and booksellers in Cracow, two-year librarianship and bookselling school in Cracow, four-year librarianship and bookselling school in Cracow. 
